\title{
Improvement of Gulf Cordgrass Range with Burning or Shredding
}

\author{
J.W. MCATEE, C.J. SCIFRES, AND D.L. DRAWE
}

\begin{abstract}
Shredding or burning during the spring, summer, or winter increased the live gulf cordgrass standing crop, decreased the dead gulf cordgrass standing crop, and increased the percentage of plants supporting inflorescences by the end of the first growing season after treatment on a clay site. The most favorable growth responses resulted from treatment in the spring, apparently because subsequent rainfall was greater than following summer treatments. Shredding generally stimulated herbaceous yields more than burning. Presumably the heavy mulch cover after shredding improved moisture relationships relative to the bare surface following fires. Burning or shredding resulted in less favorable responses on a saline fine sand than on the clay site. However, on the saline fine sand as on the clay site, shredding promoted production of gulf cordgrass more than did burning. Both methods are effective for improving gulf cordgrass range for livestock grazing, but burning is apparently the more economical alternative.
\end{abstract}

Gulf cordgrass [Spartina spartincle (Trin.) Hitchc.] is a highly productive warm-season perennial which grows in almost pure stands along the Texas coast. Stands of gulf cordgrass cover several thousand hectares, providing a potential forage resource for significant numbers of livestock (Oefinger and Scitres 1977). Gulf cordgrass provides a forage source when other vegetation is scarce, particularly during droughts. However. its coarseness and low palatability in the mature state preclude use by livestock when other range forages are available. Conversely, new shoots are relished by livestock, especially following removal of the mature, rough topgrowth. Therefore, gulf cordgrass ranges have traditionally been burned at the convenience of the land manager for use as a source of reserve feed. Burning gulf cordgrass range not only increases the palatability to grazing animals (Allen 1950) but also improves the stands for use by wildlife such as sandhill cranes (Girus canadensis L.), whooping cranes ( $G$. americana L.), Canadian geese (Branta canadensis L.) and wild turkeys 'Meleagris gallopava L.) (Personal communication, Frank Johnson, Aransas National Wildlife Refuge, Austwell, Texas. 1975). However, only recently has a concerted research effort emerged for development of prescribed burning techniques for optimizing use of gulf cordgrass range.

Although gulf cordgrass is a warm season species, it generally stays green year round under the 280- to 300-day growing

The atuhor atre, respectively, research fellow. Rob and Bessie Welder W'ildlife

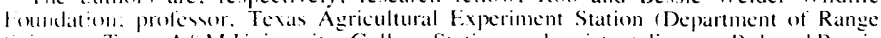
science'. Tesals Adill ( niversity. College Station: and assistant director. Rob and Bessie 11 chise 1 ildalife Foundation. Sinton. Texas.

Tinis report is approsed hy the Director. Texas Agricultural Experiment Station. as 1 A. $14^{-7}$ and by dhe Rob and Bessie Welder Wildtife Foundation as a Contribution No.

The help of Julia scifte in manuscripe preparation and typing is greatly appreciated. The atulers ate ahor grateful to J.L. Mut . R.A. Gorden. L.M. Kitchen. D. L. Embry. and

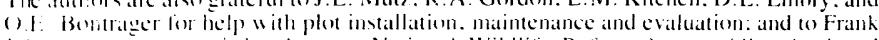

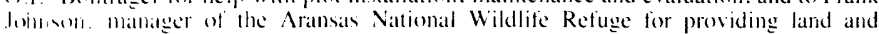

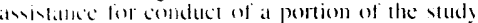

Manu-ript accined Augus 16. 1975 season of the Coastal Prairie. The mild fall and winter seasons and an average annual rainfall exceeding $90 \mathrm{~cm}$ are not conducive to adequate field curing of range forages on the Coastal Prairie. Cool season forage, aside from that furnished by Texas wintergrass (Stipa leucotricha Trin. \& Rupr.), is generally composed of low-producing annuals of the genera Hordeum and Bromus. Thus, even with a sound supplemental feeding program, condition of range livestock deteriorates significantly from late fall to early spring. Gulf cordgrass is a potential alternate source of green forage during the cool months and during the dry summer stress period if the mature, coarse topgrowth is removed to allow production of new growth which is more palatable and accessible to grazing animals. Moreover, crude protein, digestible energy, and phosphorus contents of regrowth following burning is increased significantly compared to mature topgrowth (McAtee et al. 1979; Oefinger and Scifres 1977). Previous research emphasized burning in late fall and early winter (Oefinger and Scifres 1977). However, no information was available relating new growth production to timing of top removal treatment. This study was designed to evaluate topgrowth production of gulf cordgrass following burning or shredding at various seasons.

\section{Materials and Methods}

The study was conducted on the Coastal Prairie and Gulf Coast Marshes, an area of maximum development of gulf cordgrass in Texas (McAtee et al. 1978). Experiments were located on the Rob and Bessie Welder Wildlife Refuge near Sinton and on the Aransas National Wildlife Refuge near Austwell. The gulf cordgrass community on the Welder Refuge was located between coastal marshes dominated by hydric species and coastal prairie dominated by mixed-brush (Prosopis-A(acia). Soils of the coastal marsh were Aransas-Victorial clays. which are extremely sticky and plastic when wet, cracked when $\mathrm{dry}$, and typified by slowly permeable profiles. The community on the Aransas Refuge was located between coastline vegetation, dominated by various halophytes and water-tolerant species, and live oak (Quercus virginiana Mill.) savannah on the uplands. Soil of the Aransas Refuge study site is primarily Galveston fine sand with inclusions of Veston silt loam. Annual rainfall of the study locations varies from 38 to $125 \mathrm{~cm}$, usually exceeds $90 \mathrm{~cm}$, and is characterized by peaks in the early spring and fall. Hot summers, short mild winters, and high relative humidities are characteristic of the study areas.

Burning and shredding treatments were installed on the Welder Refuge on April 11, July 10, and on December 11, 1975. Treatments on the Aransas National Wildlife Refuge were applied on June 6 and September 6,1976 . Plots, 15 by $30 \mathrm{~m}$, were surrounded by disced firelines approximately $4.6 \mathrm{~m}$ wide. Three treatments were replicated in randomized complete block designs at both locations.

Variables monitored immediately before and during burning included fine fuel load (oven-dry standing crop of gulf cordgrass, other grass plant material, standing dead herbaceous plant materials, and mulch); instaneous wind speeds and wind direction at $2 \mathrm{~m}$ with a 
hand-held anemometer; gravimetric soil-water content of five samples from 0 to $7 \mathrm{~cm}$ deep within each plot; soil temperatures at $5 \mathrm{~cm}$ deep; air temperature at $3 \mathrm{~m}$; and relative humidity at $2 \mathrm{~m}$ with a hand-held psychrometer.

All burns were installed as headfires after backfiring a safe distance, usually 5 to $7 \mathrm{~m}$. Temperatures were measured on the Welder Refuge at the soil surface, the mulch surface, the top third of the gulf cordgrass canopy, and approximately $25 \mathrm{~cm}$ above the canopy top of three individual gulf cordgrass clones during the burns using a 12-point, continuously recording thermograph. Estimates of maximum temperatures during burns on the Aransas Refuge were based on reaction of heat-sensitive tempils placed at the soil surface, within the upper third of the canopy top, and immediately above the canopy top in individual clones. Three temperature monitoring stations were placed in each plot.

Shredding treatments were installed immediately following completion of the burns. The gulf cordgrass standing crop and mulch were sampled the day before treatment, and periodically thereafter by clipping ten $0.25-\mathrm{m}^{2}$ quadrats equidistantly spaced on a diagonal across each plot. Gulf cordgrass regrowth standing crop was converted to percentages based on preburn standing crop within each plot. Data were subjected to arcsin of the square root transformation, as suggested for percentage values which cover a broad range (Steel and Torrie 1960), before conducting analysis of variance. Mean separation was accomplished with Duncan's multiple range test.

Posttreatment moisture/temperature relationships were evaluated on June 2, 1976, to aid in interpreting growth responses of gulf cordgrass to the treatments. Three mulch samples were recovered from each plot in the Welder Refuge and water content determined gravimetrically. Temperatures were recorded at $1 \mathrm{~m}$ above the soil surface, at the soil surface and at 8 and $15 \mathrm{~cm}$ below the soil surface on September 10, 1975, on plots treated on July 10, 1975, and on untreated plots on the Welder Refuge. Soil was sampled at the same time at 15,15 to 30 , and 30 to $45 \mathrm{~cm}$ deep for gravimetric determination of water content.
Foliar cover, basal cover, average plant height, number of inflorescences, and stage of inflorescence development were recorded on three permanently marked plants in each plot at 77 to 90 days after treatment on the Welder Refuge and after 28 to 30 days on the Aransas Refuge. Top weights of permanently marked plants were estimated from foliar volume measurements based on prediction equations of McAtee et al. (1978). Influence of season of treatment on average number of inflorescenses of individual gulf cordgrass plants was determined using counts for the first evaluation period in which inflorescenses appeared. Rainfall was monitored with gauges installed in the center of the study area. Each environmental variable and plant growth variable was subjected to analysis of variance and differences among means were isolated with Duncan's multiple range test.

\section{Results and Discussion}

Burns in April on the Welder Refuge were conducted with an average relative humidity of $78 \%$ and air temperature of $21.3^{\circ} \mathrm{C}$. Average wind velocity was $21 \mathrm{~km} / \mathrm{hr}$ with gusts to $25 \mathrm{~km} / \mathrm{hr}$. Total fine fuel load averaged $11,584 \mathrm{~kg} / \mathrm{ha}$ of which $24 \%$ was live, standing gulf cordgrass (Table 1). Plant diversity is typically low in these stands (McAtee et al. 1978), and standing dead fine fuel was composed primarily of gulf cordgrass. Thus, gulf cordgrass accounted for approximately $64 \%$ of the total standing fine fuel for burns in April. Estimates of standing crop also serve to indicate the relative amount of plant material deposited on the soil surface by shredding. The shredder, set about $15 \mathrm{~cm}$ above ground line to prevent damage to crowns of gulf cordgrass, deposited a continuous layer of plant residue approximately $24 \mathrm{~cm}$ deep on the soil surface, which increased weight of the mulch cover by $90 \%$ at 3 months after treatment (Table 2).

Standing crop of untreated gulf cordgrass was relatively stable for the duration of the study (Table 2). Standing crop of

Table 1. Average weight (kg/ha) of fine fuel at time of burning gulf cordgrass on the Welder Wildlife Refuge near Sinton in 1975, and on the Aransas National Wildlife Refuge near Austwell, Texas in 1976.

Fine fuel components ${ }^{1}$

\begin{tabular}{|c|c|c|c|c|c|c|}
\hline \multirow[b]{3}{*}{ Location } & \multirow[b]{3}{*}{ Burn date } & \multicolumn{5}{|c|}{ Fine fuel components ${ }^{1}$} \\
\hline & & \multicolumn{2}{|c|}{ Live plants } & \multirow[b]{2}{*}{ Standing dead } & \multirow[b]{2}{*}{ Mulch } & \multirow[b]{2}{*}{ Total } \\
\hline & & Gulf cordgrass & Other species & & & \\
\hline \multirow[t]{3}{*}{ Welder Refuge } & April & $2835 \mathrm{bc}$ & $1394 \mathrm{~cd}$ & $4520 \mathrm{~b}$ & $2835 \mathrm{a}$ & $11584 a b$ \\
\hline & July & $1778 \mathrm{a}$ & $1768 \mathrm{~d}$ & $7681 c$ & $4701 \mathrm{c}$ & $15928 d$ \\
\hline & December & $2062 \mathrm{ab}$ & $12 \mathrm{a}$ & $7326 \mathrm{c}$ & $5142 c$ & $14543 c$ \\
\hline \multirow[t]{2}{*}{ Aransas Refuge } & June & $4448 d$ & $677 b$ & 2802 a & $3316 \mathrm{~b}$ & $10942 \mathrm{a}$ \\
\hline & September & $3328 \mathrm{c}$ & 951 bd & $4283 b$ & $3359 \mathrm{~b}$ & $11921 \mathrm{~b}$ \\
\hline
\end{tabular}

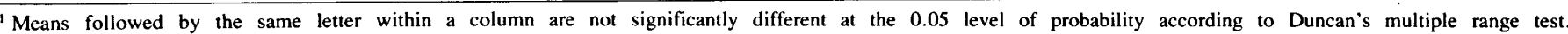

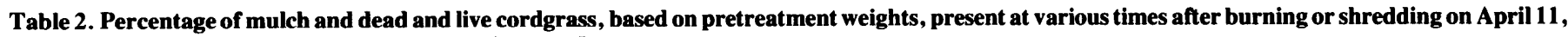
1975 on the Welder Wildlife Refuge, near Sinton, Texas.

\begin{tabular}{|c|c|c|c|c|c|c|c|c|}
\hline \multirow[b]{2}{*}{ Attribute } & \multirow[b]{2}{*}{ Treatment } & \multicolumn{7}{|c|}{ Months after treatment ${ }^{1}$} \\
\hline & & 0 & 3 & 6 & 7 & 11 & 15 & 27 \\
\hline Live cordgrass & $\begin{array}{l}\text { None } \\
\text { Burn } \\
\text { Shred }\end{array}$ & $\begin{array}{l}100 a \\
100 a \\
100 a\end{array}$ & $\begin{array}{r}90 a \\
95 a \\
154 c\end{array}$ & $\begin{array}{c}98 \mathrm{a} \\
132 \mathrm{~b} \\
169 \mathrm{~cd}\end{array}$ & $\begin{array}{l}101 \mathrm{a} \\
156 \mathrm{c} \\
202 \mathrm{~g}\end{array}$ & $\begin{array}{c}108 \mathrm{a} \\
199 \mathrm{f} \\
225 \mathrm{~g}\end{array}$ & $\begin{array}{l}101 \text { a } \\
180 \mathrm{de} \\
196 \mathrm{ef}\end{array}$ & $\begin{array}{l}102 a \\
129 b \\
154 c\end{array}$ \\
\hline Dead cordgrass & $\begin{array}{l}\text { None } \\
\text { Burn } \\
\text { Shred }\end{array}$ & $\begin{array}{l}100 \mathrm{~g} \\
100 \mathrm{~g} \\
100 \mathrm{~g}\end{array}$ & $\begin{array}{r}112 \mathrm{~h} \\
1 \mathrm{a} \\
0 \mathrm{a}\end{array}$ & $\begin{array}{c}106 \mathrm{gh} \\
7 \mathrm{a} \\
2 \mathrm{a}\end{array}$ & $\begin{array}{c}106 \mathrm{gh} \\
16 \mathrm{~b} \\
9 \mathrm{ab}\end{array}$ & $\begin{array}{r}102 \mathrm{~g} \\
27 \mathrm{c} \\
27 \mathrm{c}\end{array}$ & $\begin{array}{c}108 \mathrm{gh} \\
37 \mathrm{~d} \\
37 \mathrm{~d}\end{array}$ & $\begin{array}{c}107 \mathrm{gh} \\
72 \mathrm{e} \\
88 \mathrm{f}\end{array}$ \\
\hline Mulch & $\begin{array}{l}\text { None } \\
\text { Burn } \\
\text { Shred }\end{array}$ & $\begin{array}{l}100 \mathrm{~d} \\
100 \mathrm{~d} \\
100 \mathrm{~d}\end{array}$ & $\begin{array}{r}100 \mathrm{~d} \\
0 \mathrm{a} \\
190 \mathrm{e}\end{array}$ & $\begin{array}{r}95 \mathrm{~d} \\
0 \mathrm{a} \\
107 \mathrm{~d}\end{array}$ & $\begin{array}{c}101 \mathrm{~d} \\
4 \mathrm{ab} \\
98 \mathrm{~d}\end{array}$ & $\begin{array}{c}101 \mathrm{~d} \\
2 \mathrm{ab} \\
86 \mathrm{a}\end{array}$ & $\begin{array}{r}100 d \\
27 b \\
60 c\end{array}$ & $\begin{array}{r}103 d \\
49 c \\
49 c\end{array}$ \\
\hline
\end{tabular}

'Means within an attribute followed by the same letter are not significantly different at the 0.05 level of probability according to Duncan's multiple range test. 
live gulf cordgrass did not differ significantly among sampling dates and varied no more than $10 \%$ from pretreatment values as a result of sampling error. Following the burn in April, however, live standing crop of gulf cordgrass increased steadily for almost a year. During that time period, $69.8 \mathrm{~cm}$ of precipitation fell, about $80 \%$ of the long-term average (Drawe et al. 1978), of which $8.6 \mathrm{~cm}$ occurred during the month after treatment.

The standing crop of live gulf cordgrass had essentially doubled at 1 year after burning compared to pretreatment values (Table 2). Standing crop of green gulf cordgrass on shredded plots was greater than on burned plots after treatment in the spring at all evaluation dates, except after 15 months. This differential was attributed to the buffering effect of the heavy mulch layer against evaporation of surface soil water. Surfaces of the burned plots were essentially bare for the entire summer following burning and supported only $22 \%$ of the pretreatment mulch cover after 11 months.

During June, July, and August after burning in April, 22.6 $\mathrm{cm}$ of precipitation occurred and $27.4 \mathrm{~cm}$ were received during September and October. No standing dead gulf cordgrass occurred on plots burned or shredded for 6 months following treatment in the spring (Table 2).

As the older shoots died in late fall the year of treatment, the standing dead fraction steadily increased. However, weight of standing dead material had not been fully replaced, compared to pretreatment levels, by 27 months after burning or shredding in the spring. The proportion of live to dead standing gulf cordgrass, based on weight, was influenced by treatment at other dates as described for treatments applied in April on the Welder Refuge. In addition, changes in mulch weights from treatment were essentially the same as those related in Table 2, regardless of treatment date. Therefore, for the sake of space, only the yields of live gulf cordgrass following treatments at other dates will be discussed, regardless of location.

Based on grazing studies in South Texas, Oefinger and Scifres (1977) found that burned gulf cordgrass range could support I AU/4 ha for at least 6 months following burning largc pastures in the late fall. Under grazing pressure, regrowth is apparently stimulated so that use of standing crop data does not necessarily reflect absolute carrying capacities. However, relative comparisons in carrying capacity changes induced by treatment may be used to exemplify treatment differences. If $25 \%$ of the green standing crop is utilized by grazing animals and 12 $\mathrm{kg}$; day are required per animal unit, about $58 \mathrm{AUD}$ s/ha were available on untreated plots 6 months after spring burning. In contrast, over 78 AUD's/ha were available on burned plots and about 100 AUD's/ha on shredded areas. Potential of these treatments for altering carrying capacity is further amplified when one considers that standing, mature gulf cordgrass is of low nutritional value compared to regrowth (McAtee, et al. 1979) and is used by livestock only when other forages are not available, whereas the regrowth is readily sought out by cattle.

Burns in July were conducted under the lowest average relative humidity $(72 \%)$ of seasons of treatment evaluated and highest air temperature $\left(31.3^{\circ} \mathrm{C}\right)$. Wind velocity averaged 11 $\mathrm{km} / \mathrm{hr}$ with gusts to $17 \mathrm{~km} / \mathrm{hr}$. Green standing gulf cordgrass comprised only $1.778 \mathrm{~kg} / \mathrm{ha}$ of the fine fuel load (Table 1), about $11 \%$ of the total. The greatest proportion of the fine fuel load was comprised of standing dead plant material. Although standing fine fuel moisture content differed little from that during spring burns ( 49 and $43 \%$, respectively), the character of the fucl load and environmental conditions during the summer burn resulted in hot. sweeping fires. During the fires, an average maximum temperature of about $300^{\circ} \mathrm{C}$ was recorded between gulf cordgrass clones at the soil surface, and $425^{\circ} \mathrm{C}$ were achieved at the mulch surface. A maximum temperature of $656^{\circ} \mathrm{C}$ was achieved in the gulf cordgrass canopy and temperatures as high as $850^{\circ} \mathrm{C}$ were recorded at $30 \mathrm{~cm}$ above the canopy. The heat profile generated was exemplified by results of monitoring a typical gulf cordgrass bunch during the burn in the summer on the Welder Refuge. Highest temperatures were recorded at $2 \mathrm{~cm}$ above the canopy $\left(910^{\circ} \mathrm{C}\right)$ while lowest temperatures occurred at soil surface $\left(450^{\circ} \mathrm{C}\right.$ ) (Fig. 1). There was a lag in the attainment of temperature peaks, proceeding from the canopy top to the soil surface, but the duration of maximum temperature attained increased from the soil surface to the canopy top.

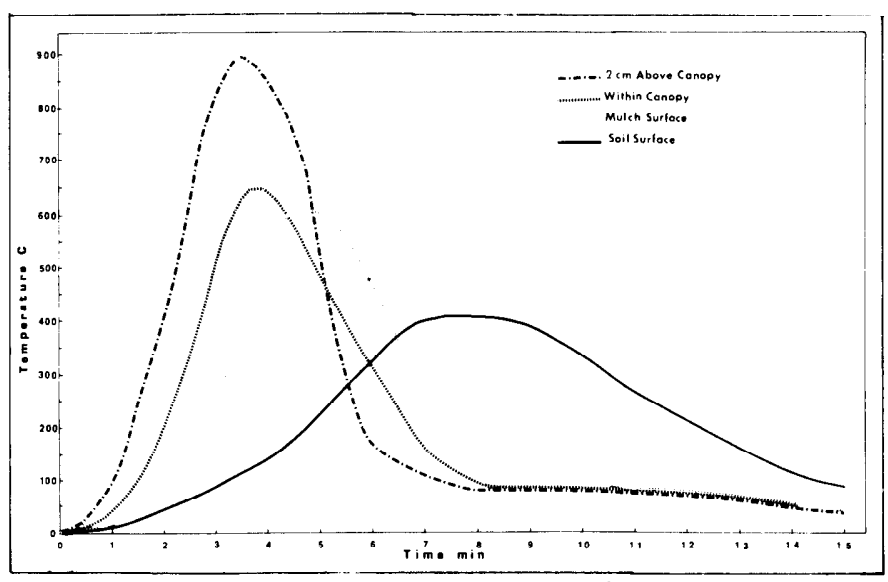

Fig. 1. Fire temperatures within a gulf cordgrass clone during the summer burn at the Welder Wildlife Refuge, Sinton, Texas.

Although replacement of topgrowth occurred more rapidly the month after treatment on shredded than on burned plots, live gulf cordgrass standing crop decreased sharply after treatment during the summer on the Welder Refuge (Table 3 ). This initial difference was attributed to $3.8 \mathrm{~cm}$ of rainfall received during the 30 days following treatment. Subsequent standing crops of green gulf cordgrass on shredded plots were significantly higher than on burned plots only at 8 months after treatment. Apparently, the heavy mulch layer caused by shredding. 3.2 times greater after 1 month than prior to treatment (data not shown), did not provide a buffer against surface moisture losses adequate to encourage significantly more regrowth than occurred following burning. Burning essentially removed the mulch cover for over 5 months, and the amount of mulch was only $43 \%$ of the

Table 3. Green gulf cordgrass as a percentage of pretreatment standing crop after burning or shredding at two dates on the Welder Wildlife Refuge near Sinton, Texas.

\begin{tabular}{|c|c|c|c|c|c|c|}
\hline \multirow{3}{*}{$\begin{array}{l}\text { Months } \\
\text { after } \\
\text { treatment }\end{array}$} & \multicolumn{6}{|c|}{ Treatment date $(1975)^{1}$} \\
\hline & \multicolumn{3}{|c|}{ July 10} & \multicolumn{3}{|c|}{ December 11} \\
\hline & None & Burn & Shred & None & Burn & Shred \\
\hline 0 & $100 \mathrm{~cd}$ & $100 \mathrm{~cd}$ & $100 \mathrm{~cd}$ & $100 \mathrm{~d}$ & $100 \mathrm{~d}$ & $100 \mathrm{~d}$ \\
\hline 0.4 & & - & - & $100 \mathrm{~d}$ & $1 \mathrm{a}$ & $4 \mathrm{a}$ \\
\hline 1 & $103 \mathrm{~cd}$ & $4 \mathrm{a}$ & $39 \mathrm{~b}$ & - & - & - \\
\hline 3 & $98 \mathrm{~cd}$ & $58 \mathrm{~b}$ & $66 \mathrm{bc}$ & $108 \mathrm{~d}$ & $27 \mathrm{~b}$ & $34 \mathrm{~b}$ \\
\hline 5 & $101 \mathrm{~cd}$ & $95 \mathrm{~cd}$ & $115 \mathrm{de}$ & - & - & - \\
\hline 6 & - & - & - & $101 \mathrm{~d}$ & $89 \mathrm{c}$ & $100 \mathrm{~d}$ \\
\hline 8 & $108 \mathrm{~d}$ & $115 \mathrm{de}$ & $154 \mathrm{f}$ & - & - & - \\
\hline 11 & $101 \mathrm{~cd}$ & $167 \mathrm{f}$ & $161 \mathrm{f}$ & - & - & - \\
\hline 18 & - & - & - & $102 \mathrm{~d}$ & $136 \mathrm{e}$ & $193 \mathrm{f}$ \\
\hline 23 & $102 \mathrm{~cd}$ & $127 \mathrm{de}$ & $142 \mathrm{ef}$ & - & - & - \\
\hline
\end{tabular}

16ath 11 ithin at treatment date followed by the same letter are nox signiticantly different all tik 0.155 level according to Duncan's multiple range test. 
pretreatment at 23 months after the fires (data not shown).

Burns during December on the Welder Refuge were conducted with the highest relative humidity $(82 \%)$ and lowest air temperature $\left(19.1^{\circ} \mathrm{C}\right)$. Average wind velocity was $11 \mathrm{~km} / \mathrm{hr}$ with gusts to $15 \mathrm{~km} / \mathrm{hr}$. Standing fine fuel load was comprised primarily of gulf cordgrass (Table 1). Standing fuel moisture content was nearly $40 \%$ but mulch moisture content was $29 \%$. Although fuel moisture contents were high, maximum fire temperatures differed little from those recorded for the summer burns which resulted in hot, sweeping fires.

Gulf cordgrass regrowth following treatment in December developed considerably slower than following burning or shredding at other seasons. Only $0.7 \mathrm{~cm}$ of rainfall were received the month following treatment, and total rainfall for January, February, and March was $1.9 \mathrm{~cm}$. By early spring, 3 months after treatment, there was no difference in the amount of regrowth following burning or shredding and green gulf cordgrass standing crop was only 27 to $34 \%$ of pretreatment values (Table 3). In contrast, regrowth was 58 to $66 \%$ of the pretreatment value by 3 months after treatment in the summer. Moreover, top growth production had completely replaced or exceeded pretreatment standing crops by the same time period after burns in the spring (Table 2). Standing crop of green gulf cordgrass was significantly reduced for at least 6 months after shredding in the winter, standing crop of green cordgrass was essentially twice that of pretreatment standing crop.

Rainfall totalled $28.7 \mathrm{~cm}$ for the 90-day period following burning in June 1976 on the Aransas Refuge. However, the stand did not respond, relative to replacement of live standing cordgrass (Table 4), as rapidly as stands treated in April Table 2) or July (Table 3) on the Welder Refuge in 1975. The reappearance of standing dead gulf cordgrass was also slower (data now shown), and the response to burning or shredding in September on the Aransas Refuge was slow compared to responses on the Welder Refuge (Table 4). By May, 8 months after treatment in September, live gulf cordgrass standing crop on burned or shredded plots was significantly less than that on undisturbed areas. It was first assumed that elimination of mulch cover from the fine sands for the 8 -month period following burning reduced rate of regrowth. However, the mulch cover was the same or higher than pretreatment values on shredded plots for the 8-month period (data not shown), and regrowth of gulf cordgrass differed little from that of plants on burned plots. Apparently, improvement of gulf cordgrass range on sandy soils has less potential than for clay soils probably because of the lower moisture-holding capacity of the sandy soil.

Differential responses of gulf cordgrass to shredding or burning on the Welder Foundation was partially explained by changes in the moisture contents of the mulch and surface soil. On June 2, 1976, mulch from untreated areas contained 35\%

Table 4. Green gulf cordgrass as a percentage of pretreatment standing crop after burning or shredding at two dates on the Aransas National Wildlife Refuge near Austwell, Texas.

\begin{tabular}{|c|c|c|c|c|c|c|}
\hline \multirow{3}{*}{$\begin{array}{l}\text { Months } \\
\text { after } \\
\text { treatment }\end{array}$} & \multicolumn{6}{|c|}{ Treatment date $(1976)^{1}$} \\
\hline & \multicolumn{3}{|c|}{ June 6} & \multicolumn{3}{|c|}{ September 6} \\
\hline & None & Burn & Shred & None & Burn & Shred \\
\hline 0 & $100 \mathrm{~d}$ & $100 \mathrm{~d}$ & $100 \mathrm{~d}$ & $100 \mathrm{~d}$ & $100 \mathrm{~d}$ & $100 \mathrm{~d}$ \\
\hline 1 & $100 \mathrm{~d}$ & $15 \mathrm{a}$ & $20 \mathrm{a}$ & $104 \mathrm{~d}$ & $7 a$ & $21 \mathrm{a}$ \\
\hline 2 & $108 \mathrm{~d}$ & $42 \mathrm{~b}$ & $58 \mathrm{~b}$ & - & - & - \\
\hline 8 & - & - & - & $103 d$ & $59 \mathrm{c}$ & $61 \mathrm{c}$ \\
\hline 12 & $103 \mathrm{~d}$ & $86 c$ & $97 \mathrm{~cd}$ & - & - & - \\
\hline
\end{tabular}

1 Meams within a treatment date followed by the same letter are not significantly different at the 0.115 level acoording 6 Duncan's multiple range test moisture. Mulch from plots burned in July or December contained only $12 \%$ moisture, whereas those shredded supported a mulch cover containing $47 \%$ moisture. Presumably, these relationships also would be reflected in soil moisture status following treatment. For example, on July 10, 1975, following treatment on September 10, the soil contained 33\% soil moisture at 0 to $8 \mathrm{~cm}$ decp. However, the surface $8 \mathrm{~cm}$ of soil from burned areas contained an average of $22 \%$ moisture whereas surface soil from shredded plots contained 35\% moisture. At the same time, when soil temperatures were 25 to $26^{\circ} \mathrm{C}$ in the surface $2 \mathrm{~cm}$ of shredded or untreated plots, they were $39^{\circ} \mathrm{C}$ on burned plots.

Both shredding and burning increased the production of inflorescences the growing season after treatment. Only 1 to $3 \%$ of the gulf cordgrass plants produced inflorescences on unplots. Following burning, from 19 to $56 \%$ of the plants produced inflorescences with the greatest percentage occurring the growing season after burning in the spring. Shredding also increased the number of inflorescences compared to no treatment but not as much as burning. From 10 to $29 \%$ of the plants produced inflorescences following shredding with the greatest percentage of plants flowering following treatments in the spring.

These data indicate considerable potential for prescribed fire or shredding for improving gulf cordgrass rangeland. Greatest potential for improvement appears to be on clay rather than sandy sites, presumably due to differences in soil moisture storage capability between soils. Burning or shredding in the spring, based on herbaceous yields, appeared more favorable than the same treatments in the summer or winter. Ths response was attributed to the more favorable moisture relationships following treatment. Sharrow and Wright (1977) reported that soil-water depletion was greater following burning than after mechanical top removal of tobosagrass (Hilaria mutica) except in ary years. The difference was attributed to the greater water demand of the luxuriant growth on burned plots. In our study, rainfall following treatments in the summer equalled that after treatments in the spring but gulf cordgrass yield was lower on plots treated in the summer. High summer air temperatures apparently accelerated moisture loss from the treated surfaces compared to treatment in the spring. especially those bared by burning.

About $1.6 \mathrm{hr} / \mathrm{hr}$ were required for shredding the rank gulf cordgrass stands in these studies. Although some initial increase in gulf cordgrass regrowth usually occurred following burning, the rising costs of fuel and labor may lend the economic advartage to prescribed burning.

\section{Literature Cited}

Allen, P.F. 1950. Ecological basis for land use planning in Gulf Coast Marshlands. J. Soil and Water Conserv. 5:57-67.

Drawe, D.L., A.D. Chamrad, and T.W. Box 1978. Plant communities on the Welder Wildlife Refuge. Welder WildI. Found. Contr. No. 5. Series B (Rev.). 39 p.

McAtee, J.W., R.D. Oefinger, and C.J. Scifres. 1978. Predicting topgrowth yield of gulf cordgrass from basal diameter and volume measurements. Southw. Natur. 23:197-204.

McAtee, J.W., C.J. Scifres, and D.L. Drawe. 1979. Digestible energy and protein content of gulf cordgrass following burning or shredding. J. Range Manage. 32:376-378.

Oefinger, R.D., and C.J. Scifres. 1977. Gulf cordgrass production, utilization and nutritional value following burning. Texas Agr. Exp. Sta. Bull. 1976. $19 \mathrm{p}$.

Sharrow, S.H., and H.A. Wright. 1977. Effects of tire. ash. and litter on soil nitrate, temperatures, moisture and tobosagrass production in the Rolling Plains. J. Range. Manage. 30:266-277.

Steel, R.G.D., and J.H. Torrie. 1960. Principles and Procedures of Statistics. McGraw-Hill Book Co., Inc. p. 158. 